\title{
Uveal Melanoma
}

National Cancer Institute

\section{Source}

National Cancer Institute. Uveal Melanoma. NCI Thesaurus. Code C7712.

A melanoma derived from melanocytes of the uveal tract. It is the most common primary intraocular tumor in the United States and Western Europe. Similar to melanoma of the skin, it is rare in Africa and Asia. Diagnostic procedures include ophthalmoscopic exam, fluorescein angiography and ultrasound. Treatment includes: surgical excision of the eye, iridocyclectomy and tumor resection. Recent treatments also include radiotherapy or photo coagulation. Classification of uveal melanomas recognizes four cell types within these tumors: epithelioid, intermediate, mixed cell, and spindle cell types. The spindle cell type uveal melanomas are further sub-classified as spindle cell type A and spindle cell type B. 